\title{
RESEARCH OF QUALITY INDICATORS OF PROTEIN- FAT MIXTURE FROM FLAX AND SESAME SEEDS FOR NUTRITION OF ATHLETES
}

\author{
Sergiy Bochkarev \\ Department of Physical Education ${ }^{1}$ \\ bochkarev.s.v@gmail.com \\ Anna Belinska ${ }^{2}$ \\ belinskaja.a.p@gmail.com \\ Oleksandra Varankina \\ Department of Biotechnology, Biophysics and Analytical Chemistry \\ avarankina@gmail.com \\ Valeriya Ananieva \\ Department of Organic Synthesis and nanotechnology ${ }^{l}$ \\ valeriya.ananieva@gmail.com \\ Igor Petik ${ }^{2}$ \\ igor171984@gmail.com \\ Andrii Koshyl \\ Department of Biotechnology, Biophysics and Analytical Chemistry \\ avkoshil@gmail.com \\ Olha Yevstifieieva \\ Department of Biotechnology, Biophysics and Analytical Chemistry \\ hob.bilbo@gmail.com \\ Kateryna Rudnieva \\ Laboratory of forensic examination \\ Emeritus Professor Mykola Bokarius Kharkiv Research Institute \\ of Forensic Sciences \\ 8 a Zolochivska str., Kharkiv, Ukraine, 61177 \\ rudneva770@ukr.net \\ ${ }^{1}$ National Technical University «Kharkiv Polytechnic Institute» \\ 2 Kyrpychova str., Kharkiv, Ukraine, 61002 \\ ${ }^{2}$ Ukrainian Scientific Research Institute of Oils and Fats \\ of the National Academy of Agricultural Sciences of Ukraine, \\ 2A Dziuba ave., Kharkiv, Ukraine, 61019
}

\section{Abstract}

The aim of the research is to determine the microbiological stability of a protein-fat mixture of flax and sesame seeds that allows to correct its storage life. A protein-fat mixture has a high content of irreplaceable amino acids BCAA and polyunsaturated fatty acids of $\omega$-3group, so it may be positioned as a component of nutrition for athletes. Flax and sesame seeds, cultivated in Ukraine, were used as research materials. The product was created, based on comminuted flax and sesame seeds in ratio 1:1.

There were determined organoleptic (outlook, taste, smell, color) and physical-chemical (mass share of moisture, ash, protein, fat, acidic, peroxide, anisidine number) parameters of the product. There was determined the microbiological stability of the protein-fat mixture of the increased food value for athletes nutrition after 6 months. It has been proved, that as opposite to the control sample, the protein-fat mixture of the developed composition manifests its microbiological stability by the following 
parameters: content of mesophilic aerobic and facultative anaerobic microorganisms, molds, yeast, bacteria of the colon bacillus group and pathogenic microorganisms. The control sample that is comminuted flax seeds doesn't manifest at the end of the storage term any correspondence of microbiological parameters by the content of mesophilic aerobic and facultative anaerobic microorganisms, molds, and bacteria of the colon bacillus group. This regularity is explained by the presence of lignans, sesamol and sesamoline, with preservative properties in the developed product. The obtained data may be used for reasoning recipes of products, based on the protein-fat mixture and correction of the food supplements ratio in them.

Keywords: protein-fat mixture, flax seeds, sesame seeds, oxidative stability, microbiological stability, sesamol, sesamoline.

DOI: $10.21303 / 2504-5695.2019 .001001$

\section{Introduction}

Raw materials and ingredients, included in the composition of products of a special destination, particularly, for athletes' nutrition, must be high-quality, safe and have a high purification degree $[1,2]$. Such products must be made, observing requirements of the Alimentarius Code for products of special and child nutrition [3].

It is known, that fat-containing products are disposed to two types of spoilage - chemical (oxidative) and microbiological ones. A spoilage type that limits storage terms of these products is determined by the following factors:

- fat mass share;

- moisture mass share;

- fatty-acid composition of the fatty phase;

- initial indices of oxidation of the fatty phase (acidic, peroxide, anisidine numbers);

- initial microbiological parameters (number of mesophilic aerobic and facultative anaerobic microorganisms, molds, yeast, bacteria of the colon bacillus group and pathogenic microorganisms);

- presence of natural antioxidants and preservatives and so on [4-8].

For increasing oxidative and microbiological stability, the aforesaid factors are affected and also a series of food supplements, preventing oxidative and microbiological spoilage, are applied $[9,10]$.

Works [11-14] substantiate the composition of the protein-fat mixture of the increased food value for athletes' nutrition, based on oil seeds, investigate its antioxidant properties and also determine technical processing parameters, at which the maximal increase of the biological value of the products is possible.

The aim of the research is to determine organoleptic and physical-chemical parameters and also microbiological stability of a protein-fat mixture of flax and sesame seeds for athletes' nutrition. These data will be applied for reasoning recipes of a series of products, for example, confectionary ones, based on the protein-fat mixture and correction of food supplements (antioxidants and preservatives in them).

\section{Materials and Methods}

The following materials were used for conducting the studies:

- flax seeds (Ukraine, RI of oil crops of NAAS) by SSU 4967;

- sesame seeds (Ukraine, RI of oil crops of NAAS) by SSU 7012.

The protein-fat mixture of the increased food value for athletes' nutrition is comminuted flax and sesame seeds in ratio 1:1. Comminuted flax seeds are used as a control sample.

Photos of the obtained samples are presented on Fig. 1.

Preparation of the protein-fat mixture includes the following stages:

- mixing of flax and sesame seeds;

- comminution of seeds to $150 \ldots 200 \mathrm{mcm}$ in the knife vertical comminutor Glasser (RF);

- moisture-thermal processing, using a source of microwave radiation according to [14].

The protein-fat mixture for athletes' nutrition has the high content of irreplaceable amino acids BCAA (branched-chain amino acids) - leucine, isoleucine, valine. The ratio of polyunsaturated fatty acids of $\omega-6$ and $\omega-3$ groups is near 3:1. The protein-fat mixture may be used as an in- 
dependent product and also in the composition of fat-containing products for athletes in the period of intensive physical loads, for soldiers, workers of hard physical labor under changing climatic conditions and other population layers [11].

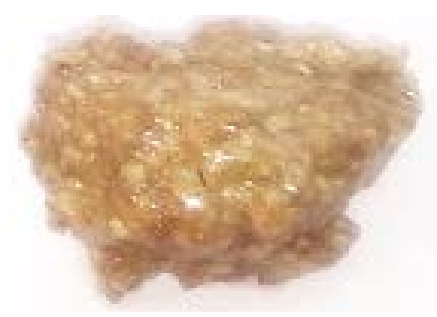

$a$

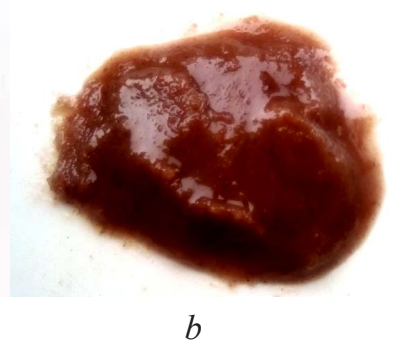

$b$

Fig. 1. Photos of samples of the protein-fat mixture $(a)$ and control sample (comminuted flax seeds) $(b)$

Organoleptic parameters of the protein-fat mixture (outlook, taste, smell, color) were determined according to SS 27988 "Oil seeds. Methods of color and smell determination". The moisture mass share was determined according to SSU 4603 "Oils. Methods of moisture mass share and volatile substances determination". The ash mass share was determined according to SS 26226 "Fodders, mixed fodders, mixed fodder raw materials. Methods of raw ash determination". The fat mass share was determined according to SS 10857 "Oil seeds. Methods of oil content determination". The mass share of protein was determined according to SS 7169 "Fodders, mixed fodders, mixed fodder raw materials. Methods nitrogen and raw protein determination". The acidic number of fat in the protein-fat mixture was determined according to SS ISO 660 "Animal fats and vegetable oils. Method of acidic number and acidity determination", peroxide number - according to SSU ISO 3960 "Animal fats and vegetable oils. Method of peroxide number determination", anisidine number - according to SSU ISO 6885 "Animal fats and vegetable oils. Method of anisidine number determination".

Samples for microbiological analyses were taken and prepared according to SS 26669 "Food and taste products. Preparation of samples for microbiological analyses". The number of mesophilic aerobic and facultative-anaerobic microorganisms was determined according to SSU ISO 4833 "Microbiology of food products and animal fodders. Horizontal method of microorganism calculation". The number of bacteria of the colon bacillus group (coliforms) was determined according to SS 30518 "Food products. Methods of revelation and determination of the number colon bacillus group bacteria". The number of bacteria of Salmonella genus was determined according to SSU EN 12824 "Microbiology of food products and animal fodders. Horizontal method of Salmonella revelation". The number of molds and yeast fungi was determined according to SSU ISO 7954 "Microbiology of food products and animal fodders. General instructions of yeast and microscopic molds calculation".

\section{Experimental procedures}

Organoleptic and physical-chemical parameters of samples of the protein-fat mixture (PFM) of the increased food value, based on flax and sesame, and also control sample, based on flax seeds, were determined at the room temperature and presented in Table $\mathbf{1 .}$

The studied (sesame and flax seeds) and control (flax seeds) samples of the protein-fat mixture were kept in the closed polyethylene pack in the aerial medium during 6 months at temperature $10{ }^{\circ} \mathrm{C}$. The storage time at the given temperature was chosen, based on data, set in technical conditions for analogous products. At the beginning and at the end of storage the samples were examined for the following microbiological parameters: content of mesophilic aerobic and facultative anaerobic microorganisms (Fig. 2), yeast (Fig. 3) and molds (Fig. 4). There were conducted the studies of samples of the protein-fat mixture for the presence of colon bacillus group bacteria and pathogenic microorganisms, including Salmonella genus (Table 2). The presence of microorganisms in samples was compared with the maximum permitted value, indicated in normative documents (ND). 
Table 1

Organoleptic and physical-chemical parameters of protein-fat mixtures of the increased food value

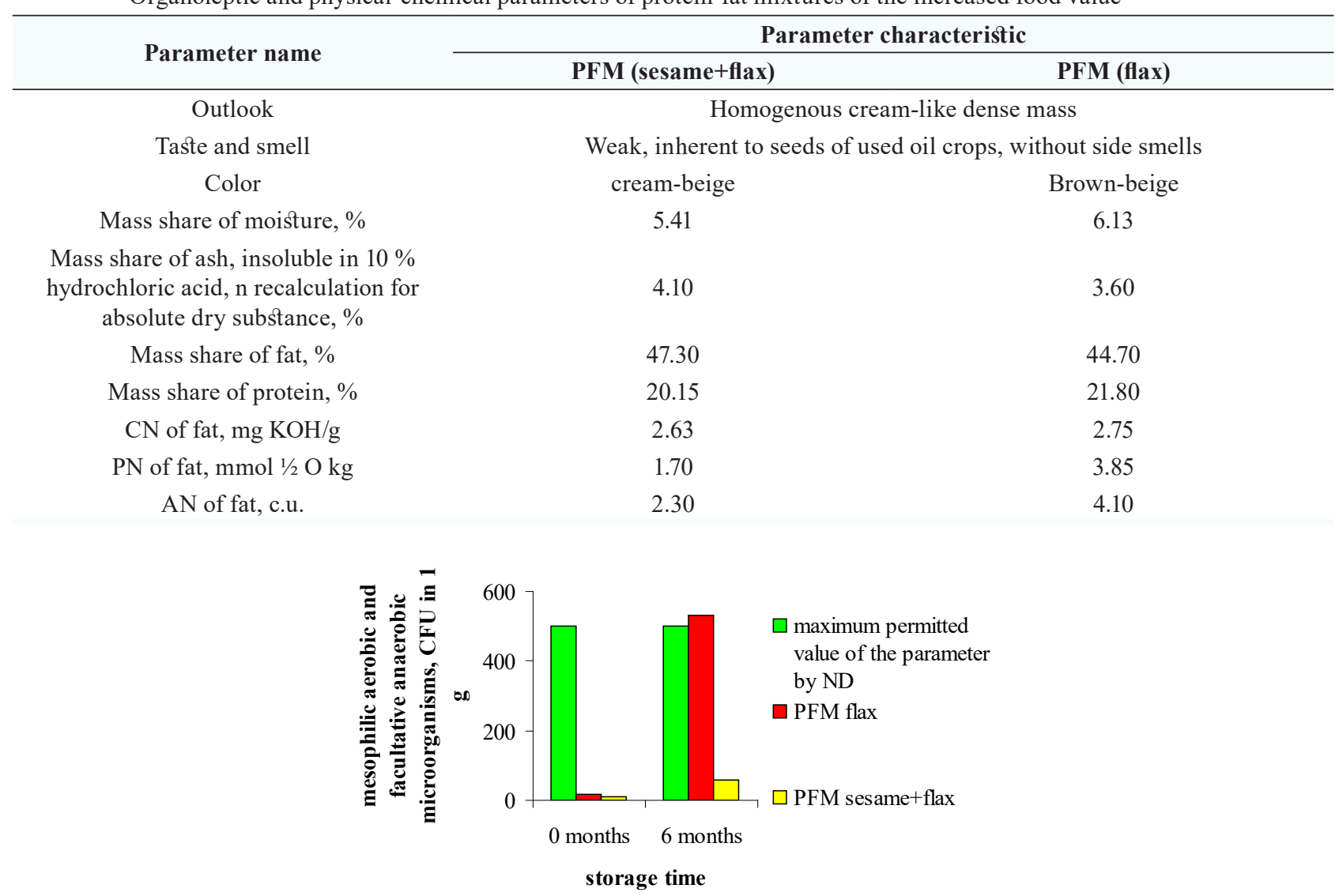

Fig. 2. Dynamics of changes of the content of mesophilic aerobic and facultative anaerobic microorganisms in the studied products

As it is seen from Fig. 2, the content of mesophilic aerobic and facultative anaerobic microorganisms in the protein-fat mixture of flax and sesame seeds after 6 months of storage doesn't exceed values, permitted by normative documents. As to the control sample, after 6 months of storage this parameter exceeds the norm. The results testify that components of the protein-fat mixture with flax seeds have preservative properties that allow them to inhibit the growth of mesophilic aerobic and facultative anaerobic microorganisms.

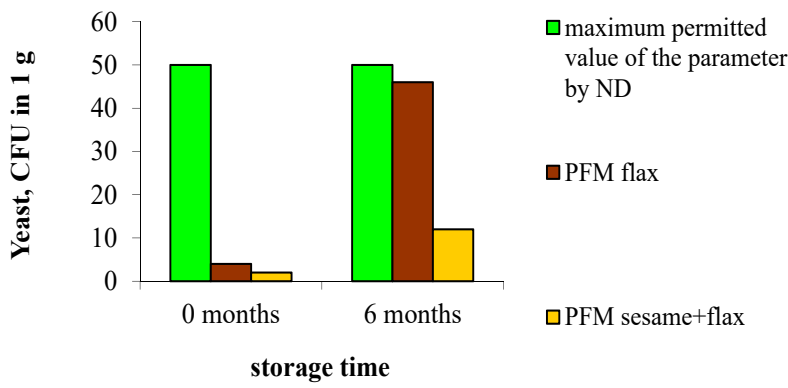

Fig. 3. Dynamics of changes of the yeast content in the studied products

As it is seen on Fig. 3, the content of yeast spores in both flax and sesame seeds protein-fat mixture and control sample after 6 months doesn't exceed values, maximally permitted by normative documents. The obtained results testify that the yeast content in samples is not a crucial indicator of the microbiological stability of the product. 


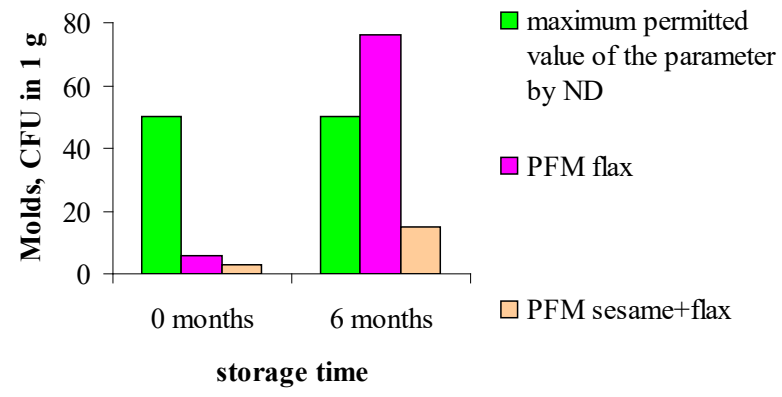

Fig. 4. Dynamics of changes of the mold content in the studied products

As it is seen on Fig. 4, the content of mold spores in the flax and sesame seeds protein-fat mixture after 6 months doesn't exceed values, maximally permitted by normative documents. As to the control sample, the content of molds in it after 6 months of storage was 76 CFU in $1 \mathrm{~g}$ of the product that exceeds the maximum permitted index (50 CFU in $1 \mathrm{~g}$ of the product). The obtained results testify that compounds, included in the composition of the protein-fat mixture with sesame seeds, have preservative properties that allow them to inhibit the growth of molds.

Table 2

Presence of colon bacillus group bacteria and pathogenic microorganisms, including ones of Salmonella genus in the studied products

\begin{tabular}{|c|c|c|c|c|c|}
\hline \multirow{3}{*}{ Parameter name, measuring units } & \multirow{3}{*}{$\begin{array}{l}\text { Parameter value } \\
\text { by ND }\end{array}$} & \multicolumn{4}{|c|}{ Test results } \\
\hline & & \multicolumn{2}{|c|}{0 months } & \multicolumn{2}{|c|}{6 months } \\
\hline & & \multicolumn{2}{|c|}{ PFM (sesame+flax) } & \multicolumn{2}{|c|}{ PFM (flax) } \\
\hline $\begin{array}{l}\text { Colon bacillus group bacteria (coliforms) } \\
\text { in } 0,1 \mathrm{~g}\end{array}$ & Not nern & Not revealed & Not revealed & Not revealed & 6 \\
\hline $\begin{array}{l}\text { Pathogenic microorganisms, particularly } \\
\text { bacteria of Salmonella genus in } 25 \mathrm{~g}\end{array}$ & ivot permilted & Not revealed & Not revealed & Not revealed & Not revealed \\
\hline
\end{tabular}

As it is seen from Table 2, no colon bacillus group bacteria and pathogenic microorganisms, including bacteria of Salmonella genus, were revealed in the protein-fat mixture of flax and sesame seeds after 6 months of storage. As to the control sample, the coliforms, not permitted by normative documents, appear in the product after 6 months of storage. Bacteria of Salmonella genus in the control sample are not revealed during the whole storage term. The obtained results testify that components of the protein-fat mixture with flax seeds have preservative properties that allow them to inhibit the growth of colon bacillus group bacteria. As to the content of pathogenic microorganisms, in particular, bacteria of Salmonella genus are not a crucial indicator of the microbiological stability of the product.

\section{Discussion}

There were studied organoleptic and physical-chemical parameters of samples of the protein-fat mixture of the increased food value, based on flax and sesame, and also the control sample - based on flax seeds. The obtained indices (Table 1) little differ from each other. An exclusion is only indices of the content of initial (peroxide number) and secondary (anisidine number) oxidation products. The sample, based on flax seeds, has higher oxidation indices that testify to the less lipid stability of the product already at the stage of its obtaining. It may be explained by the high content of polyunsaturated fatty acids in lipids of flax seeds. Comparing with the control, the sample of the developed product is more stable to oxidative spoilage at the expanse of sesame antioxidants (sesamol and sesamoline) presence in it [15-18].

The studies of the microbiological stability of the protein-fat mixture and the control product were conducted (Fig. 2-4, Table 2). After 6 months of storage the developed product manifests the higher microbiological stability by the following parameters: content of mesophilic aerobic and 
facultative anaerobic microorganisms, molds, yeast, bacteria of the colon bacillus group and pathogenic microorganisms. These parameters don't exceed normative ones after finishing the storage term. As to the control sample, at the end of the storage term it didn't correspond to requirements of normative documents by the content of mesophilic aerobic and facultative anaerobic microorganisms, molds, bacteria of the colon bacillus group and pathogenic microorganisms. This regularity is explained by the presence of lignans of sesame, sesamol and sesamoline with preservative properties, testified by studies $[19,20]$. It may be supposed with the high reliability degree, that the preliminary technological processing of the preliminarily moisturized protein-fat mixture (exposition in the field of microwave radiation), offered in [14, not only raises the assimilability degree of proteins in the product at the expanse of inactivating inhibitors of proteolytic enzymes, but favors the increase of microbiological stability of the product.

\section{Conclusions}

It has been determined, that the protein-fat mixture, based on flax and sesame seeds, has the higher oxidative and microbiological stability, comparing with the control sample. The reserch results proved the microbiologcal stability of the developed product after 6 months of storage. It must be taken into account by developers of recipes and producers of food products, containing the protein-fat mixture, based on flax and sesame seeds, for example, fat-containing confectonary products.

Shortcomings of this study are the absence of data about sesame lignans content (sesamol and sesamoline) in the studied samples of the protein-fat mixture and their correlation with the microbiological stability indices. In its turn, a weak side of the study is an accent on the one type of raw materials, containing natural components, preventing oxidative and microbiological spoilage of the product. That is why it is expedient to search for similar raw materials and to develop products on their base for increasing the content of synthetic food supplements (antioxidants and preservatives) in products for increasing their food value and, correspondingly, decreasing the potential toxicity from synthetic components.

\section{References}

[1] Kodeks Alimentarius. Gigiena pishchevyh produktov (2007). Moscow: Izdatel'stvo "Ves' Mir".

[2] Mikrobiolohichni pokaznyky dlia kharchovykh produktiv (2005). Rehlament komisiyi EC No. 2073/2005.

[3] Kodeks Alimentarius. Produkty dlya spetsial'nogo, v tom chisle mladencheskogo i detskogo pitaniya (2007). Moscow: Izdatel'stvo "Ves' Mir".

[4] Davidson, P. M., Harrison, M. A. (2002). Resistance and adaptation to food antimicrobials, sanitizers, and other process controls. Food Technology, 56 (11), 69-78.

[5] Rawat, S. (2015). Food Spoilage: Microorganisms and their prevention. Asian Journal of Plant Science and Research, 5 (4), $47-56$.

[6] Singer, A. C., Shaw, H., Rhodes, V., Hart, A. (2016). Review of Antimicrobial Resistance in the Environment and Its Relevance to Environmental Regulators. Frontiers in Microbiology, 7. doi: https://doi.org/10.3389/fmicb.2016.01728

[7] Bielinska, A. P. (2011). Tekhnolohiya kupazhovanoi oliyi pidvyshchenoi biolohichnoi tsinnosti. Kharkiv, 23.

[8] Maszewska, M., Florowska, A., Dłużewska, E., Wroniak, M., Marciniak-Lukasiak, K., Żbikowska, A. (2018). Oxidative Stability of Selected Edible Oils. Molecules, 23 (7), 1746. doi: https://doi.org/10.3390/molecules23071746

[9] Kim, J., Kim, D. N., Lee, S. H., Yoo, S.-H., Lee, S. (2010). Correlation of fatty acid composition of vegetable oils with rheological behaviour and oil uptake. Food Chemistry, 118 (2), 398-402. doi: https://doi.org/10.1016/j.foodchem.2009.05.011

[10] Sarafanova, L. A. (2004). Pishchevye dobavki. Entsiklopediya. Sankt-Peterburg: GIORD.

[11] Bochkarev, S., Matveeva, T., Krichkovska, L., Petrova, I., Petrov, S., Belinska, A. (2017). Research of the oilseeds ratio on the oxidative stability of the protein-fat base for sportsmen. Technology Audit and Production Reserves, 2 (3 (34)), 8-12. doi: https://doi.org/10.15587/2312-8372.2017.96665

[12] Bochkarev, S., Varankina, O., Bielykh, I., Samoilenko, S., Zviahintseva, O. (2018). Correction of technological characteristics of protein-fat mixture by expanding the component composition. Technology Audit and Production Reserves, 5 (3 (43)), 33-36. doi: https://doi.org/10.15587/2312-8372.2018.146122

[13] Bochkarev, S., Cherevichna, N., Petik, I., Belinska, A., Varankina, O., Zakhozhyi, O. et. al. (2017). Development and research candies with increased biological value with protein-fat composite. EUREKA: Life Sciences, 6, 16-21. doi: https:// doi.org/10.21303/2504-5695.2017.00504 